\title{
Community in Transition: Amana's Great Change, 1931-1933
}

\author{
PETER HOEHNLE
}

The first generation has an idea and lives for that idea. The second generation perpetuates that idea for the sake of their fathers, but their hearts are not in it. The third generation openly rebels against the task of mere perpetuation of institutions founded by their grandfathers-it is always the same with people.

-F. William Miller, Main Amana pharmacist, $1933^{1}$

IN THE SUMMER of 1855 a line of wagons pulled onto a tract of woods and prairie in Iowa County, Iowa, carrying 33 men and women, the vanguard of the 1,200-member Ebenezer Society. Within a decade of its relocation from near Buffalo, New York, to the sparsely settled Iowa prairies, the Society, now known as the Amana Society, established seven villages on 26,000 acres of Iowa timber and farmland. At its height, with more than 1,800 members, a large communal farm, and woolen, calico, and flour mills, the Amana Society was one of the largest, best known, longest lived, and most financially successful communal groups in the United States. ${ }^{2}$ By 1931, however, both internal and external pressures had induced third-generation members of the So-

\section{Des Moines Register, 22 October 1933.}

2. Communal societies that have lasted longer than the Amana Society include the Harmony Society of Pennsylvania (1805-1905), the Hutterites of the Northern Great Plains (1874-present), and the Shakers (1774-present).

THE ANNALS OF IOWA 59 (Winter 2001). (C) The State Historical Society of Iowa, 2001. 
ciety to consider abandoning the communal system whose roots had been planted in Iowa in 1855. Its members hoped that such drastic action would provide for the future well-being of their church and economy in an environment that would no longer support communal living as they had known it.

Despite the fame the Amana Society has achieved and the considerable scholarly work its history has attracted, scant attention has been directed toward the remarkable process by which the Society successfully reorganized. ${ }^{3}$ And none of the authors who have previously dealt with the reorganization had available to them the original voting ballots, correspondence, and some of the oral histories used in this study. ${ }^{4}$ These sources

3. Although more than 30 theses and dissertations have been written on aspects of the Amana Society, my study of the reorganization, "The Great Change: The Reorganization of the Amana Society, 1931-1933" (M.A. thesis, Iowa State University, 1998), was the first such study undertaken in the discipline of history, although studies in other fields have used forms of historical perspective. Most scholarly studies, and even popular works on the Society, understandably focus on the communal period. Jonathan Andelson, in his landmark dissertation, "Communalism and Change in the Amana Society, 1855-1932" (Ph.D. diss., University of Michigan, 1974), devoted only five pages to the reorganization. Lawrence Rettig, Amana Today, briefly surveyed the process of reorganization, as did Bertha M. H. Shambaugh in her early work, Amana That Was and Amana That Is (Iowa City, 1932). Barnett Richling's, "The Amana Society: A History of Change," Palimpsest 58 (1977), 34-47, deals primarily with the years prior to reorganization, as does Tom Phillips and Mary Phillips, Amana: Metamorphosis of a Culture (Cedar Rapids, 1973). Pamela Heard Shumway's "Amana: Governance Structures and Religious Beliefs" (Ph.D. diss., George Mason University, 1995), is based almost entirely on Andelson's data and, like Diane Barthel's Amana: From Pietist Sect to American Community (Lincoln, NE, 1984), includes little original research and virtually no primary sources. Arthur Barlow, the longtime business manager of the Amana Society after the reorganization, wrote a charming, yet brief, memoir of his involvement with the Society, The Amana Society's "Great Change" (Cedar Rapids, 1971), which provides an interesting view of the events of that era. Other sources that deal with the reorganization are Keith Sculle, "Amana's First Decisions about Roadside Architecture: An Index of Cultural Change," Annals of Iowa 49 (1988), 462-74; Gary Carman, "The Amana Colonies' Change from Communalism to Capitalism in 1932," Social Science Journal 24 (1987), 157-67; Jonathan Andelson, "The Community of True Inspiration from Germany to the Amana Colonies," in America's Communal Utopias, ed. Donald E. Pitzer (Chapel Hill, NC, 1997); and idem, "The Double-Bind and Social Change in Communal Amana," Human Relations 34 (1981), 111-25.

4. Much of this material was in the possession of my great-grandfather, Peter Stuck, who died in 1979, leaving behind cabinets full of his personal papers, memorabilia, and photographs. Following his death, his son-in-law, my grand- 
reveal that the reorganization of the Amana Society was a proactive measure undertaken by concerned leaders within the organization in order to establish business and religious institutions to preserve aspects of the old Society before financial necessity forced the group into receivership or dissolution. Reorganization was not inevitable at the time that it took place. Rather, its proponents worked hard in a successful effort to convince an overwhelming majority of members of the Society to support reorganization. Once members had approved a plan for reorganization, a lengthy transition period ensued during which Amana residents became accustomed to working for wages, owning their own homes, cooking in those homes, and otherwise asserting their new-found independence. Reorganization did not mean an "end" to community life. Instead, while communal living was abandoned, the Society's shops, mills, and farms - newly organized into a corporation-continued to provide employment for residents. Moreover, the Amana Church Society, representing the reorganized religious elements of the old Society, continued as the spiritual backbone of the community. ${ }^{5}$

THE ROOTS of the Amana Society lay in the religious upheavals occurring in the German states during the late seventeenth and early eighteenth centuries. At that time, groups of Lutheran dissidents known collectively as Pietists began to protest the ceremony and pomp of the established churches and sought to

father, Arthur Selzer, laboriously indexed and filed most of those papers. Later, I discovered he had overlooked some material-two small boxes, including the ballots from the June 1931 test vote and dozens of pieces of correspondence and miscellaneous material relating to the reorganization process itself. That material has proved an invaluable source of previously unavailable information. Besides his personal papers, my great-grandfather, as secretary of the reorganization committee, and later secretary of the Amana Society Board of Directors, kept most of the minutes I have used for this study. And as editor of the Amana Society Bulletin, he produced many of the journalistic accounts I have used.

5. The Amana Society's reorganization was so successful, in fact, that it led noted communal scholar Donald Pitzer to formulate a theory of "developmental communalism" to describe instances in which communal groups, in one form or another, survived beyond their communal stage. Donald E. Pitzer, "Developmental Communalism: An Alternative Approach to Communal Studies," in Utopian Thought and Communal Experience, ed. Dennis Hardy and Lorna Davidson (Enfield, England, 1989), 68-76. 
bring individuals closer to God through an emphasis on personal religious experience. Many Pietist groups believed in some form of divine inspiration; some separated from established religious tradition and began meeting as separate religious sects. ${ }^{6}$

In 1714 two noted Pietists, Eberhard Ludwig Gruber and Johann Friedrich Rock, established a Pietistic community in the region surrounding Frankfurt that became known as the Community of True Inspiration. The Inspirationists believed that certain individuals, known as Werkzeuge, or "instruments," were inspired to issue the Word of the Lord. For more than a century the group suffered persecution, decline, and revival in the German states. In the 1820s scattered Inspirationist congregations began to congregate on large estates in the province of Hesse-Darmstadt. The community leader at that time, Christian Metz, and his fellow elders established a quasi-communal form of life on the estates. Members worked on farms leased in common and in woolen factories established to provide employment for them.

In 1842, facing the threat of further persecution, Metz led the Inspirationists to New York State, where they purchased a 5,000-acre tract they named Ebenezer. There they created a formal communal system, in which all land and property was held in common, families ate in central kitchens, and church elders meted out job assignments. ${ }^{8}$ Although originally established as a temporary measure to pay for both the passage of poorer members to America and the cost of the land purchase, the elders continued the system because they recognized the benefits to be gained from communal life. Formal sanction of the communal way came from the biblical Book of Acts, where there is evidence that the first Christian church had held all things in common, and from a testimony through Christian Metz, who

6. Andelson, "Communalism and Change," 12-15; William Rufus Perkins and Barthinius L. Wick, History of the Amana Society (Iowa City, 1891), 5-9.

7. Andelson, "Communalism and Change," 15-43; Perkins and Wick, History of the Amana Society, 10-43; Bertha M. H. Shambaugh, Amana: The Community of True Inspiration (Iowa City, 1908), 22-59.

8. The best source on the Ebenezer period of the Amana Society is still Frank J. Lankes, The Ebenezer Community of True Inspiration (Gardensville, NY, 1949). 
proclaimed, "the Lord says: as truly as I live, it will never be my intention to sever those close bonds of our community. . . . shame and disgrace shall come over those who work against it. Their children shall go hungry and have no blessing.", Communal living, originally intended to serve an economic function, was, in this way, sanctioned by religion. The leaders of the Society, however, while using religious dogma to bolster communalism, never took the step of making it an absolute article of faith for the community. ${ }^{10}$

In the 1850 s, seeking a location removed from the temptations of the outside world where there was also plentiful and cheap land, the group moved west to Iowa. There, for over three-quarters of a century, communal living flourished in the seven villages that became known as the Amana Society.

By 1931, however, cracks had appeared in the formidable structure of the Amana Society. Christian Metz died in 1867. His successor as Werkzeug, Barbara Landmann, died in 1883. Since that time there had been no charismatic leader. While the elders maintained a semblance of religious authority over their people, religious enthusiasm waned. Fewer and fewer people regularly attended the eleven church services held weekly. The decline of religious authority also meant a loss of control over Society members in the work force. Some members simply saw no reason to work hard since, under the communal system, they continued to receive food, shelter, and clothing regardless of their effort. A few even feigned long bouts of "illness" to avoid work altogether. Young members of the Society chafed at church restrictions on bobbed hair, baseball, and modern conveniences deemed "worldly" by the elders. Many young people simply left the Society, and its population declined from a high of 1,813 in 1881 to 1,365 by 1932 . Gradually, the elders permitted aspects of mainstream life to penetrate the Amana Society. By 1931, the

9. Acts 3:44-45 ("And all that believed were together, and had all things in common ... a and parted [their possessions] as every man needed"); Christian Metz, Testimony, 19 March 1854, translated by Magdalena Schuerer, Amana Heritage Society, Main Amana.

10. Frank M. Moore, "The Amana Society, 1867-1932: Accommodation of Old World Beliefs in a New World Frontier Setting" (Ph.D. diss., Vanderbilt University, 1988), 227. 
people of the Amana Society had begun to look very much like their counterparts in surrounding communities. ${ }^{11}$

At the same time, the financial health of the group suffered as a result of worsening economic conditions in rural Iowa in the 1920s. The farm recession after the First World War greatly reduced the profits of Society farms and woolen mills. Profits were needed to pay the large number of hired workers and to stock community stores with the consumer goods the members of the group increasingly demanded. The Society's debt continued to mount, reaching $\$ 500,000$ by $1931 .{ }^{12}$ In this perilous environment, Society leaders began to consider significantly altering the communal structure in order to address the internal and external forces that threatened it.

Ironically, while the Society suffered financially, its members were largely shielded from the effects of the larger depression developing in the outside world. One young Amana man, sent by Society leaders to study embalming in New York City, was shocked at the conditions he found there. "It wasn't until I went to New York, and saw how people lived there-[standing] in breadlines and selling apples on the street corners, that I realized how bad it was. ${ }^{\prime 13}$ The Society still provided food, clothing, and shelter for its members, but the increasingly debt-ridden, insular organization faced an economic catastrophe of such magnitude that it would soon no longer be able to shield its members from financial disaster.

THE AMANA SOCIETY'S reorganization movement originated with a small group of professional men who began meeting during 1930. The group included Dr. Charles F. Noé, Peter Stuck, and F. William Miller of Main Amana, and Dr. Henry G. Moershel and William Ehrle Jr. of Homestead. The group repre-

11. Shambaugh, Amana That Was and Amana That Is, 360-70; Andelson, "Community of True Inspiration," 194-95.

12. William F. Moershel, "Statement of Liquitable Assets and Liabilities," 4 April 1934, author's collection. A more recent analysis of the Society's prereorganization business records clearly demonstrates that the Society was headed for bankruptcy. Carman, "The Amana Colonies' Change," 157-67.

13. Carl Eichacker, interview with Emilie Zuber Hoppe, 1981, typed transcript, Oral History Collection, Amana Heritage Society. 
sented the elite of the Society. Four of the men had been educated outside the community at Society expense to serve as doctors, a pharmacist, and a schoolteacher. The fifth man, William Ehrle, was a store clerk. They were far from a disaffected group of people; all had ready access to the Society's power structure. Noé and Miller were church elders, and Noé's brother was a church trustee. ${ }^{14}$ Stuck's father-in-law was the secretary of the board of trustees and the head elder for the village of Main Amana. The five men were related by marriage or proximity. Noé and pharmacist Miller were brothers-in-law, Ehrle and Stuck were first cousins by marriage, and Stuck was a cousin of all but Miller through his wife's family. Three of the menMiller, Noé, and Stuck-were virtually next-door neighbors in Main Amana, and all three ate at the communal kitchen managed by Noé's wife, Louise. Moershel, in addition to being related to Stuck, had shared a house with Miller's family as a young man and had been Ehrle's lifelong neighbor. All five men had demonstrated a tendency toward reformist attitudes. As early as 1925, Moershel had written to Society elders about his ideas for reforming the Society, and he, Stuck, Miller, and Noé had promoted such changes as allowing children to play baseball and girls to bob their hair. ${ }^{15}$

Responding, presumably, to the suggestions of these advocates of reform, the trustees of the Society decided, at their meeting on March 16, 1931, to appoint a committee of four to explain the Society's worsening financial condition to the members and to provide for the election of a committee to decide on a course of action. ${ }^{16}$ At a series of meetings-one in each village-the

14. Moershel and Stuck later became elders in 1931 and 1951, respectively. Register of All Elders from 1817 (Middle Amana, 1970).

15. Henry G. Moershel to William F. Moershel, 28 August 1925, author's collection. Biographical information is based on the necrology file and collection of obituary clippings at the Amana Heritage Society and on informal conversations with surviving family members. A recently published book brings to light another connection between these men: Miller, Moershel, and Stuck were all avid photographers. Abigail Foerstner, Picturing Utopia: Bertha Shambaugh and the Amana Photographers (Iowa City, 2000).

16. Minutes, Amana Society Board of Trustees, 16 March 1931, Amana Society Archives, Amana Society main office, Main Amana. The members of this committee were all church elders: Peter Zimmermann, the manager of the Amana Woolen Mill; Gustav Miller, manager of the West Amana Store; Ad- 
committee explained the financial state of the Society and, it appears, made a case for drastic change. ${ }^{17}$ One Main Amana resident recalled the meeting in her village, at which a conservative elder suggested that the Society could survive if everyone was united in the effort. She was stunned when the equally conservative secretary of the Society rose and stated that he believed reorganization was the only possible course of action. She concluded that "if he thinks so ... I bet that's the way we should go." ${ }^{18}$

Following the April meetings, members of the Society elected another committee to further consider a course of action, with each village electing one delegate for every 25 residents. Little campaigning occurred, probably because of the Society's repeated criticism of the "party spirit" found in the outside world. The Society and its members tended to disassociate themselves from political divisions, even within the Society itself. ${ }^{19}$ On the other hand, reflecting outside influence on the Society, women as well as men over the age of 21 participated in the election. (Before the Society amended its constitution in 1930, unmarried women over the age of 31 were the only women permitted to vote in Society-wide elections. ${ }^{20}$ )

The 47 men elected to the committee shared several broad characteristics. Ranging in age from 21 to 60 , the committee was unusually young, with an average age of 40 , far lower than the church trustees' average age of 62. A large number of the com-

olph Heinemann, a bookkeeper and traveling salesman for the Society; and Dr. Carl Noé. At the time, Zimmermann and Miller were also church trustees, and both later served as presidents of the Society. Noé and Heinemann were also later elected to serve as trustees.

17. Barbara S. Yambura, A Change and a Parting: My Story of Amana (Ames, 1960), 276-77.

18. Helene Schmieder Rind, interview with author, Middle Amana, 17 March 1998, tape recording in author's collection.

19. Fred Blechschmidt, interview by Emilie Zuber Hoppe, 20 March 1981, typed transcript, Oral History Collection, Amana Heritage Society, Amana; Paul E. Kellenberger to the author, 16 June 1997, author's collection. Kellenberger is the last surviving member of the Committee of Forty-Seven, and his insight helped clarify my understanding of that body.

20. This amendment to the Society's constitution followed, by over a decade, the national amendment granting women the vote. Despite the patriarchal nature of the group, however, a woman, Barbara Landmann, had been its spiritual leader for 17 years in the late nineteenth century. 
mittee members had spent time outside the Society. At least 12 had been sent away by the Society for further education. Society members apparently favored individuals with some experience on the "outside" or who had more education than the average Society member, who generally received only an eighth-grade education. This affinity for candidates who had spent time outside the community, coupled with the high number of votes received by such vocal advocates of reorganization as Peter Stuck, suggests that Society members were reconciled to reorganization and elected those individuals they felt would best be able to accomplish it. ${ }^{21}$

These trends were less true for the village of Middle Amana, where the reorganization was to meet great resistance. Although the Middle Amana delegation was, like the rest of the committee, fairly young, only two of the Middle Amana representatives had been educated outside the colonies, and fewer of its representatives were professional men.

The individual village committees met separately throughout the reorganization process, but the reorganization process was primarily the responsibility of the General Committee that was composed of members from each village committee. The first meeting of the General Committee, consisting, at that point, of all 47 local committee members, convened at Main Amana on May 2, 1931. At that meeting the delegates decided that, in order to be more effective, the General Committee would need to be halved. The reconstituted General Committee allowed each village one delegate for every 50 residents, chosen from the individuals who had received the highest vote totals from their respective villages that April. The committee selected John Eichacker, the Homestead postmaster, as president, F. William Miller as vice-president, and Peter Stuck as secretary. ${ }^{22}$ Both Stuck and Miller had been among the original advocates of

21. Pollbook, Election of the Delegates, Village of Amana, 23 April 1931, author's collection. Biographical information on the members of the Committee of Forty-Seven is based on a set of necrology records at the Amana Heritage Society, the obituaries of members in local papers, primarily the Amana Society Bulletin, and the official birth and death records of the Amana Church Society, now in the possession of, and maintained by, the author.

22. Minutes of the General Committee, 2 May 1931, Amana Society Archives. 
organization in the spring of 1931. In the weeks that followed, the local committees reconvened occasionally to advise the delegates to the General Committee. ${ }^{23}$

In May, two of the committee delegates from Main Amana, Peter Stuck and William Noé, drafted a ballot and letter to be used to gauge Society members' opinion on the possibility of reorganization. The two men took the draft to their local committee, where it was discussed. ${ }^{24}$ Then they presented the letter and ballot to the General Committee, which approved it and planned for its distribution. The ballot asked respondents two questions (translated from the original German as follows):

1. Is it in your opinion possible to go back to the old life of denial exactly as it is prescribed [in the accompanying letter], and are you and your family willing to lead this life without reservation?

2 . Is it in your opinion possible that by reorganization ... the building-up of our community can be effected according to Article $\mathrm{V}$ of our present Constitution, and are you and your family willing to present your plans and views before the Committee and to coöperate in carrying out the plan approved by the Trustees and the majority of the members? ? $^{25}$

Respondents were asked to answer "yes" or "no" to both questions. In order to be counted as a vote in favor of reorganization a respondent had to answer "yes" to the second question. Several individuals apparently assumed that a "no" answer to the first query implied their acquiescence to reorganization, but the committee did not count their votes in that way. Consequently, support for reorganization may have been even greater than the vote totals indicate. ${ }^{26}$

23. The advisory capacity of the local committees is revealed in the Amana Local Committee Minutes and in letters sent to the General Committee by the local committees of East Amana, West Amana, and Homestead, all of which are in the author's collection.

24. Minutes, Amana Local Committee, 11 May 1931, Amana Society Archives.

25. The translation of the ballot questions used here is found in Shambaugh, Amana That Was and Amana That Is, 374-75.

26. It is evident that this is the manner in which the votes were counted when one looks at the percentage of support tabulated for each village. For example, in High Amana only 10 people out of 63 total voters voted "no" on the second question. The percentage of support for reorganization from High Amana, 
TABLE 1

VOTING RESULTS FROM JUNE 17, 1931, REFERENDUM

\begin{tabular}{|c|c|c|c|c|c|c|c|}
\hline \multirow{2}{*}{ Village } & \multirow{2}{*}{$\begin{array}{l}\text { No. } \\
\text { Sent }\end{array}$} & \multirow{2}{*}{$\begin{array}{l}\text { No. } \\
\text { Ret'd }\end{array}$} & \multicolumn{2}{|c|}{ Question \#1 } & \multicolumn{2}{|c|}{ Question \#2 } & \multirow{2}{*}{$\begin{array}{l}\% \text { in } \\
\text { favor }\end{array}$} \\
\hline & & & Yes & No & Yes & No & \\
\hline Homestead & 118 & 117 & 3 & 101 & 113 & 3 & 96 \\
\hline South Amana & 110 & 110 & 6 & 103 & 106 & 2 & 96 \\
\hline Main Amana & 270 & 261 & 6 & 253 & 251 & 6 & 93 \\
\hline West Amana & 88 & 87 & 6 & 54 & 81 & 5 & 92 \\
\hline East Amana & 64 & 63 & 13 & 45 & 42 & 2 & 66 \\
\hline High Amana & 63 & 63 & 10 & 52 & 33 & 10 & 52 \\
\hline Middle Amana & 204 & 199 & 65 & 122 & 50 & 117 & 25 \\
\hline TOTALS & 917 & 900 & 109 & 730 & 676 & 145 & 74 \\
\hline
\end{tabular}

Source: Lawrence Rettig, Amana Today: A History of the Amana Society from 1932 to the Present (South Amana, 1975), 123.

As expected, following the informational meeting held in April that had painted a rather bleak picture of the Society's prospects, support for reorganization ran high throughout most of the villages. Most members of the Society realized that changes of one form or another had to be made. If they didn't, the lengthy letter that accompanied the ballot spelled out in detail the sacrifices members would need to make if they wished to continue the communal system. ${ }^{27}$

Support for reorganization was particularly strong in South, West, and Main Amana and Homestead, villages that lay along highways or rail lines. Communities not along highways or rail lines with little interaction with outsiders were less inclined to favor reorganization, as were elderly members of the Society. ${ }^{28}$

however, was reported as only 52 percent, because only 33 of the 63 eligible voters voted "yes" on the second question, while 20 left it blank. Thus, it is clear that, in order for a ballot to be counted as being in favor of reorganization, the second question had to be answered in the affirmative. Had the committee simply counted a "no" response to the first question as being in favor of reorganization, the percentages in favor would have been much higher -82 rather than 52 percent in the case of High Amana.

27. A translation of the letter is in folder 10, Amana Society Collection, State Historical Society of Iowa, Iowa City, and is transcribed as appendix B in my master's thesis, "The Great Change," 166-72; original in author's collection.

28. The ballots and memories of surviving residents support the claim that opposition came largely from the elderly. I discovered the signed, original ballots from this election among the papers of my great-grandfather, Peter Stuck. 
There appears to be no correlation between place of birth and opposition to reorganization, as opposition appears to have been equally divided between members who emigrated from Germany and those who were born in the United States. ${ }^{29}$ Despite some opposition, support for reorganization was nearly unanimous in some villages. In Homestead, only four people opposed reorganization, three of whom were members of the same immediate family. In both Main and East Amana opposition was almost entirely contained within two families. In the six villages other than Middle Amana, 89 percent supported reorganization.

Middle Amana, alone of all the villages, opposed reorganization. With only one-quarter of its residents in favor of reorganization, Middle Amana fell 30 percent lower than the next lowest total, that of High Amana. The reasons for Middle Amana's intransigence have been a topic of debate in the Amana community for almost 70 years. A primary cause for the opposition was the leadership of John Heinemann, a highly respected and beloved church elder and trustee who openly opposed any plan to abandon the old way of life. Heinemann was the only church trustee to vote against reorganization.

The vote in Middle Amana stood in sharp contrast to voting trends of the other villages. While the church elders in the other towns were virtually unanimous in their support of reorganization, those in Middle Amana were not. While support in other villages came from younger people and opposition from the elderly, in Middle Amana opposition came from all age brackets. Some current Amana residents suggest that Heinemann's leadership may have been only one of several causes for the unusual response from Middle Amana. Some say that Middle Amana residents feared that an outside interest was encourag-

They are now in the author's collection. For residents' memories that opposition came from the elderly, see Marie Blechschmidt, interview with Kirk W. Setzer, 8 March 1982, typed transcript, Oral History Collection, Amana Heritage Society.

29. I was able to determine the place of birth of each respondent by using the genealogy files of the Amana Heritage Society. Of the 46 opposition voters not from Middle Amana that I found records for, 23 were born in Germany and 23 were born in the United States. 
ing the Society to abandon communal living in order to gain control of the woolen mills. Others suggest that some residents of Middle Amana viewed reorganization as a project forced on them by the longstanding rival towns of Main Amana and Homestead. $^{30}$ Another plausible explanation is that Middle Amana's somewhat isolated location meant it had less contact with "outsiders" and was therefore less dissatisfied with the restrictions of communal living. However, Middle Amana was only two miles from Main Amana, and East Amana, an equal distance from Main Amana, demonstrated far stronger support for reorganization. Some evidence suggests that certain members of the Middle Amana delegation to the General Committee - the only members of that committee to vote against reorganization-misled or otherwise encouraged residents to join in opposition.

Whatever the reasons for Middle Amana's intransigence, it led to widespread mockery of the village by the rest of the Society. A humorous poem about Middle Amana, titled Zum Nachdenken (In Reflection), circulated throughout the Society. The poet proclaimed that once the village had exhausted its sources of food and money, the people would regret their opposition to reorganization. The poem mirrored the comments of frustrated Middle Amana delegate William Heinze, who once noted at a General Committee meeting that as long as his constituents received bread and wine, they would be happy. ${ }^{31}$

The General Committee interpreted the vote as a clear mandate to proceed with reorganization, and presented the returns and their conclusion to the board of trustees. The trustees authorized them to proceed. Later that July the Committee of Twenty-Three created a Committee of Ten to draft a plan for

30. Helene Schmieder Rind interview. This rivalry can be demonstrated by the Middle Amana residents' insistence, when their post office was established in 1933, that it be legally called "Middle, Iowa" rather than "Middle Amana."

31. Authorship of this poem, part of a long tradition of humorous verse within the Society, is a matter of controversy within Amana today. It is generally acknowledged however, that the author was very likely from Main Amana. William Heinze's comment about Middle Amana was recalled by his associate on the General Committee, Adolph T. Berger, in an interview with Emilie Zuber Hoppe, quoted in Emilie Zuber Hoppe, "A Story Recalled," unpublished paper, 1981, 15, Amana Heritage Society. 


\begin{tabular}{|c|c|}
\hline enken & on \\
\hline $\begin{array}{l}\text { Die Fragenzettel sind jetzt hier, } \\
\text { Es prangt Nein, Nein auf dem Papier; } \\
\text { Und Mittel denkt es hatt gewahlt } \\
\text { So wie es sich am besten stellt. }\end{array}$ & $\begin{array}{l}\text { The question-sheets are now received, } \\
\text { And no, no the papers read; } \\
\text { And Middle thinks that it has voted } \\
\text { The way that will serve it best. }\end{array}$ \\
\hline $\begin{array}{l}\text { In Mittel scheints ist gut genung } \\
\text { So lang noch nicht ganz leer der Krug, } \\
\text { So lang als wie der Speck noch reicht, } \\
\text { So lang kann lebeb man noch leicht. }\end{array}$ & $\begin{array}{l}\text { In Middle the status quo is good enough } \\
\text { As long as there is something in the jug, } \\
\text { As long as the bacon is still rich, } \\
\text { As long as the living is easy. }\end{array}$ \\
\hline $\begin{array}{l}\text { Und wenn noch ein Leib Brot ist da, } \\
\text { Warum sollt' man dann schreiben "Ja" } \\
\text { Als Antwort auf die Frag die schon } \\
\text { Hin deut auf Reorganization? }\end{array}$ & $\begin{array}{l}\text { For when a store of bread is here, } \\
\text { Why should one write "Yes" } \\
\text { As answer to the question } \\
\text { To worthlessly proceed to reorganization? }\end{array}$ \\
\hline $\begin{array}{l}\text { So lebt man weiter sorgenlos } \\
\text { Bis alles fort und die Not grosz, } \\
\text { Der Krug wird leer, der Speck ist all, } \\
\text { Dann kommt das End mit lautem Knall. }\end{array}$ & $\begin{array}{l}\text { So one continues, free from care } \\
\text { Until all is gone and great the need, } \\
\text { The jug is empty and the bacon gone, } \\
\text { Then the end will come with a bang. }\end{array}$ \\
\hline $\begin{array}{l}\text { So gar das gute Brot fehlt jetzt, } \\
\text { Und Mittel wird in dreck gesetzt. } \\
\text { Sie hatten sich so weit vergessen, } \\
\text { Sich selbst aus Heim und Haus gefress. }\end{array}$ & $\begin{array}{l}\text { Even the good bread is gone now, } \\
\text { And Middle is set in the dirt. } \\
\text { They forgot themselves so completely, } \\
\text { That they've eaten themselves from house } \\
\text { and home. }\end{array}$ \\
\hline $\begin{array}{l}\text { Wenn's so weit ist, } \\
\quad \text { dann hoert man schrein, } \\
\text { Warum hab ich geschrieben "Nein," } \\
\text { Damals als ich mit Spott und Hohn, } \\
\text { Veract die Reorganization. }\end{array}$ & $\begin{array}{l}\text { When this has come to pass, } \\
\text { one will hear the cry, } \\
\text { Why did I vote "No," } \\
\text { When I, with mocking scorn, } \\
\text { Rejected the Reorganization. }\end{array}$ \\
\hline
\end{tabular}

SOURCE: Poets and Poetry Collection, folder 5, box 1, Amana Heritage Society. Translated by Peter Hoehnle.

reorganization. That committee followed four basic criteria propounded by Main Amana delegate William Miller: any plan should provide for the preservation of the church and the care of the elderly and establish procedures for residents to acquire their homes and secure employment. ${ }^{32}$

The Committee of Ten, which included Miller, Stuck, and Moershel from the original advocates of reform, met frequently over a two-week period to draft a plan that the General Com-

32. Minutes, General Committee, 15 July 1931, Amana Society Archives. 
mittee subsequently approved. ${ }^{33}$ At that point the committee sought legal counsel from the Attorney General of Iowa, John Fletcher, a longtime friend of William F. Moershel, the secretary of the Amana Society. Fletcher agreed to act in a friendly advisory capacity, and his assistant, Oral Swift, soon became the committee's principal legal advisor. Swift was particularly well suited to assist the Amana Society. He had spent most of his early life in nearby Marengo, where he had practiced law from 1925 to 1929 and where his father remained a prominent attorney. ${ }^{34}$

During meetings of the General Committee in October and November, Swift presented various drafts of a formal plan of reorganization. The General Committee ultimately approved a plan on January 2, 1932. Because approval of the plan was crucial, the General Committee called all the delegates from the various local committees into a marathon session at Main Amana. When the vote was taken, 39 of the 46 members present (one was absent) approved the plan, and all pledged to support it to present a unified front before the members. ${ }^{3}$

Copies of the reorganization plan were printed and distributed among the members of the Society. Members of the committee lobbied to convince members to approve the plan. Most members of the Society were fully aware of the perils the organization faced and the benefits to be gained from reorganization, and they trusted the men they had selected to plan reorganization. For proponents of the plan, approval was a do-ordie situation; rejection would have been the first step towards bankruptcy and receivership. Fortunately, by the winter of 1932 few can have doubted that the majority of an educated and trusting membership would approve the plan.

At a formal election on February 2, 1932, over 96 percent of the members of the Society voted in favor of the reorganization plan. In most villages the vote was unanimous, or nearly so.

33. The members of the Committee of Ten were Ferdinand Ruff, South Amana; Carl Flick, West Amana; Henry Bendorf, High Amana; William Heinze, Middle Amana; Louis Hess Jr., East Amana; William Noé, Amana; and Dr. Henry G. Moershel of Homestead. John Eichacker, F. William Miller, and Peter Stuck, as officers of the General Committee, served as at-large delegates.

34. Iowa Press Association, Who's Who in Iowa (Des Moines, 1940), 1018.

35. Minutes, General Committee, 2 and 13 January 1931, Amana Society Archives. 
Sino Sie damit einverftanden, dẩ der vorge: fhlagene Plan, die Zlmana Society ju reorganifie: ren, welcher Jhnen fürjlich jur Durchitḩt vorgelegt wurde, angenommen und ausgeführt wird?

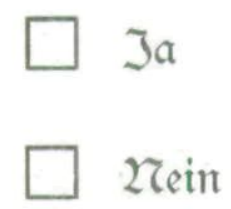

This ballot was mailed to all members of the Amana Society in February 1932. Courtesy Peter Hoehnle.

Even in Middle Amana, over 89 percent approved the plan. Seven individual copies of the plan were distributed to the villages for the members to sign. All members, including those who had voted against the plan, eventually signed at the insistence of Society leaders who wanted to appear united to the outside world. $^{36}$

The plan the members approved in February 1932 established a joint stock corporation to be known as the Amana Society, which would assume all of the business interests of the old communal society. Each member of the old Society would receive one share of membership stock in the new corporation, which would entitle them to receive free medical and burial services from the Society. In addition, each member would receive one prior distributive share for each year of service they had given the old society above the age of 21 , allowing older members enough stock to cash in their shares one by one for living expenses. Homes were to be appraised and members would be given several months to purchase their homes using their stock shares. After that time, those who had not purchased their homes would be assessed a minimal rent. The church was to be completely separated from the business aspects of the Society and

36. Emilie Zuber Hoppe, "Amana's Quiet Revolution," Wilkommen 6 (Winter 1987), 11. 
TABLE 2

VOTING RESULTS ON APPROVAL OF REORGANIZATION PLAN, FEBRUARY 1, 1932

\begin{tabular}{lrrc}
\hline Village & Yes & No & \% Approval \\
\hline High Amana & 62 & 0 & 100 \\
West Amana & 88 & 1 & 99 \\
Homestead & 116 & 1 & 99 \\
Main Amana & 267 & 4 & 99 \\
East Amana & 64 & 1 & 98 \\
South Amana & 102 & 11 & 90 \\
Middle Amana & 186 & 23 & 89 \\
\hline \multicolumn{1}{c}{ TotALS } & 885 & 41 & 96 \\
\hline
\end{tabular}

SOURCE: Results as reported in the Marengo Pioneer-Republican, 4 February 1932.

allowed to reorganize itself, which it did the following December when the Amana Church Society formally incorporated.

OUTSIDE OBSERVERS expressed keen interest in the Amana Society's "Great Change." For many, particularly commentators who feared the infiltration of communism in depression-era America, the reorganization of the Amana Society marked the "end" of the "world's most perfect example of Communistic success. ${ }^{\prime 37}$ Newspapers ranging from the New York Times to the Pasadena Post editorialized on the failure of "communism" in Iowa. That the Amana Society's form of communal living was dramatically different from that practiced in the Soviet Union was lost on these commentators, as was the fact that the Amana Society, rather than converting to pure capitalism, had actually formed a cooperative.

Unlike their national counterparts, who relied on wire copy for their editorials, Iowa journalists, such as Harvey Ingham of the Des Moines Register and Henry A. Wallace of Wallaces' Farmer, were well acquainted with the Amana Society and wrote knowl-

37. Pasadena Post, 17 January 1933. The idea that the Amana Society's reorganization proved the impracticality of communism was voiced by the Society's own business manager in his memoir, and was revived as late as 1989 when East and West Germany were reunified. Barlow, The Amana Society's "Great Change," 1-2; John F. Stehle, "How Some Communists Became Capitalists Overnight," Wall Street Journal, 29 November 1989. 
edgeably about its reorganization. Wallace, in particular, took an unusual interest in the state of affairs in Amana. In a June 1931 letter to the Society president, he offered, "to help . . . if you think I could be of service in any way." ${ }^{138}$ During the spring of 1932, Wallace began to correspond with Dr. Henry Moershel of Homestead, soon to become the president of the new Amana Society. Moershel apparently initiated the correspondence by asking Wallace to recommend someone to serve as farm manager for the Society. Wallace supplied a list of likely candidates, although the Society ultimately decided not to hire a professional farm manager. Once the lines of communication had been opened, Wallace apparently saw no reason to close them. He wrote to Peter Stuck, suggesting ways the Society could develop a woodworking industry, and to Moershel, suggesting individuals who might help with other aspects of the reorganization process. Wallace's April 29 letter to Moershel contained perhaps his most unusual advice. He suggested that, in order to save money, the Society might want to promote a new diet among its members. "If your people wish to have the maximum of welfare with the minimum of work," he wrote, "it would seem to me they should consider living as nearly as possible on dairy and vegetable products." Wallace's vegetarian plan was never adopted, but Amana leaders highly regarded his advice on other matters, particularly agricultural ones.

In some of his correspondence with Moershel and in an editorial he wrote about the reorganization for Wallaces' Farmer, Wallace revealed his deep interest in cooperative associations. In the letter to Moershel, Wallace wrote, "you can avoid falling too much for the lure of capitalism. To have your people fall for this at a time when capitalism is just beginning to display its most glaring weakness would be tragic indeed." ${ }^{\prime 39}$ In his editorial, published on July 9, 1932, Wallace asserted that the reorganized Amana Society "furnished a sociological and economic laboratory which may point the way out of some of our diffi-

38. Henry A. Wallace to John [sic] Heinemann, 17 June 1931, microfilm reel 7, frame 652, Henry A. Wallace Papers, Microfilm Department, Parks Library, Iowa State University, Ames.

39. Henry A. Wallace to Henry G. Moershel, April 1932, microfilm reel 13, Henry A. Wallace Papers. 
culties ... if we are right about this matter." ${ }^{40}$ Wallace's interest in and impact on the Society continued even after he became U.S. Vice President in 1941.

DURING THE WEEKS following the vote, a period of pretransition began. In March and April appraisers descended on the communities. Surveyors laid out lot lines where such lines had never existed. The outside appraisers, assisted by appointed Society members, inventoried every piece of machinery in the various shops and helped the kitchen workers catalog and appraise all the items in the various kitchen houses. A team from Iowa State College, headed by Anson Marston, dean of the engineering department, conducted the appraisals of the two woolen mills, six saw mills, one flour mill, three grain elevators, one soap factory, four hotels, and 162 shops, including the various bakeries, slaughterhouses, basket shops, blacksmith shops, broom shops, cabinet and carpenter shops, cooper shops, harness shops, machine shops, tailor shops, shoe shops, and wagon shops found in the seven villages. ${ }^{41}$

The first and perhaps most significant change wrought by reorganization occurred on April 11, when the communal kitchens served their last meal. So momentous was the occasion that the Des Moines Tribune sent a photographer and reporter to Amana to capture the scene, where, the reporter claimed, "smiles and laughs rather than tears prevailed." ${ }^{42}$ That sense of elation, however, was not universal. A West Amana woman recalled, years later, happily preparing the final meal at her kitchen house when she noticed an older woman start to cry; soon everyone in the kitchen was in tears. ${ }^{43}$ A South Amana woman voiced the feelings of many at the loss of camaraderie among the kitchen workers, when, 50 years after the reorganization, she lamented, "I missed the kitchens and the girls I worked with. Sure, it was

40. "The Amana Society is Reorganized," Wallaces' Farmer, 9 July 1932, 5.

41. One of Marston's student assistants, Charles G. Parsons, wrote his master's thesis based on the Amana valuations: "Valuation of the Industrial Property of the Amana Society" (M.S. thesis, Iowa State College, 1932).

42. Des Moines Tribune, 11 April 1932.

43. Emilie Zuber Hoppe, Seasons of Plenty (Ames, 1994), 219. 


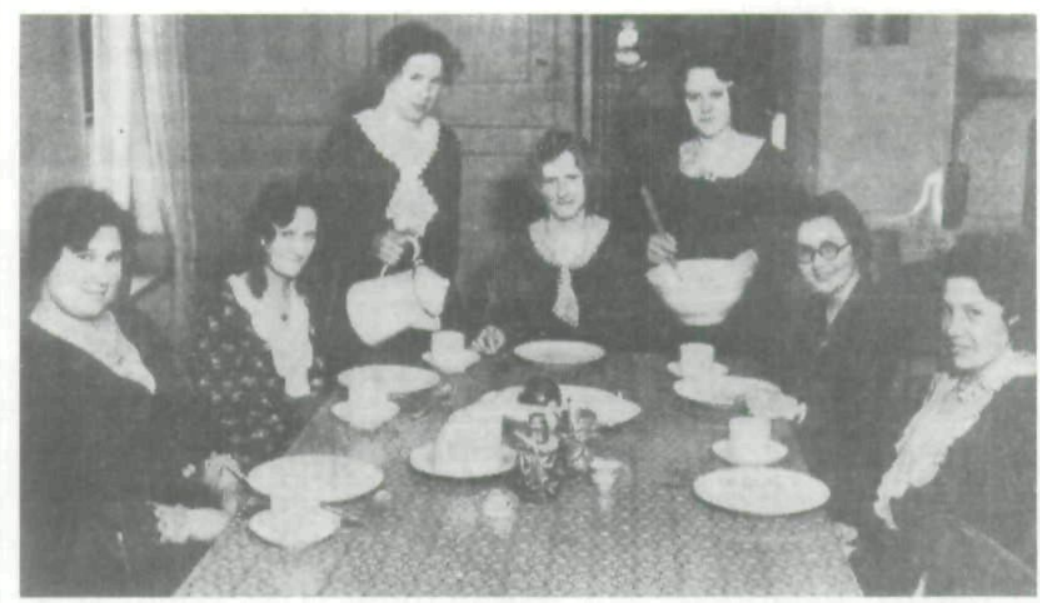

A group of Amana women pose for a Des Moines Tribune photographer as they eat their last meal in one of the communal kitchens. Left to right around the table: Henrietta Dittrich, Louisa Kippenhan, Lizzie Seifert Dittrich (with coffee), Henrietta Roemig, Louise Schmieder Fels, Maria Eichacker, and Louisa Berger. From Des Moines Tribune, April 11, 1932.

easier to cook for my husband and myself instead of [for] thirty people, but I missed the girls in the kitchen. ${ }^{\prime 44}$

Soon after the close of the kitchens, the kitchen workers were allowed to choose items such as cooking utensils for themselves. The remaining items were sold. West Amana held five auctions on the same April day. A crowd of people moved from one auction to another, purchasing items with credit against their, as yet, unissued prior distributive shares. ${ }^{45}$ Local photographer Rudolph Kellenberger captured the poignant scenes at the West Amana auctions, creating a rare visual record of the reorganization. ${ }^{46}$

44. Emilie Zuber Hoppe, "A Story Recalled," unpublished paper, Amana Heritage Society, 1981, 13, quoting Minnie Setzer, then of High Amana, who had worked in the communal kitchens for 30 years prior to the reorganization.

45. At least one Amana mother, conscious of the need to conserve as much of the prior distributive stock value as possible, cautioned her daughter against reckless spending at the kitchen auctions. Lina Roth Unglenk, personal conversation with the author, 8 March 1998, notes in author's collection.

46. For Kellenberger's photography, see “One Man's Record: The Amana Photographs of Rudolph Kellenberger," Iowan 33 (Fall 1984), 43-50; and Foerstner, Picturing Utopia, 48-51, 78, 79. 


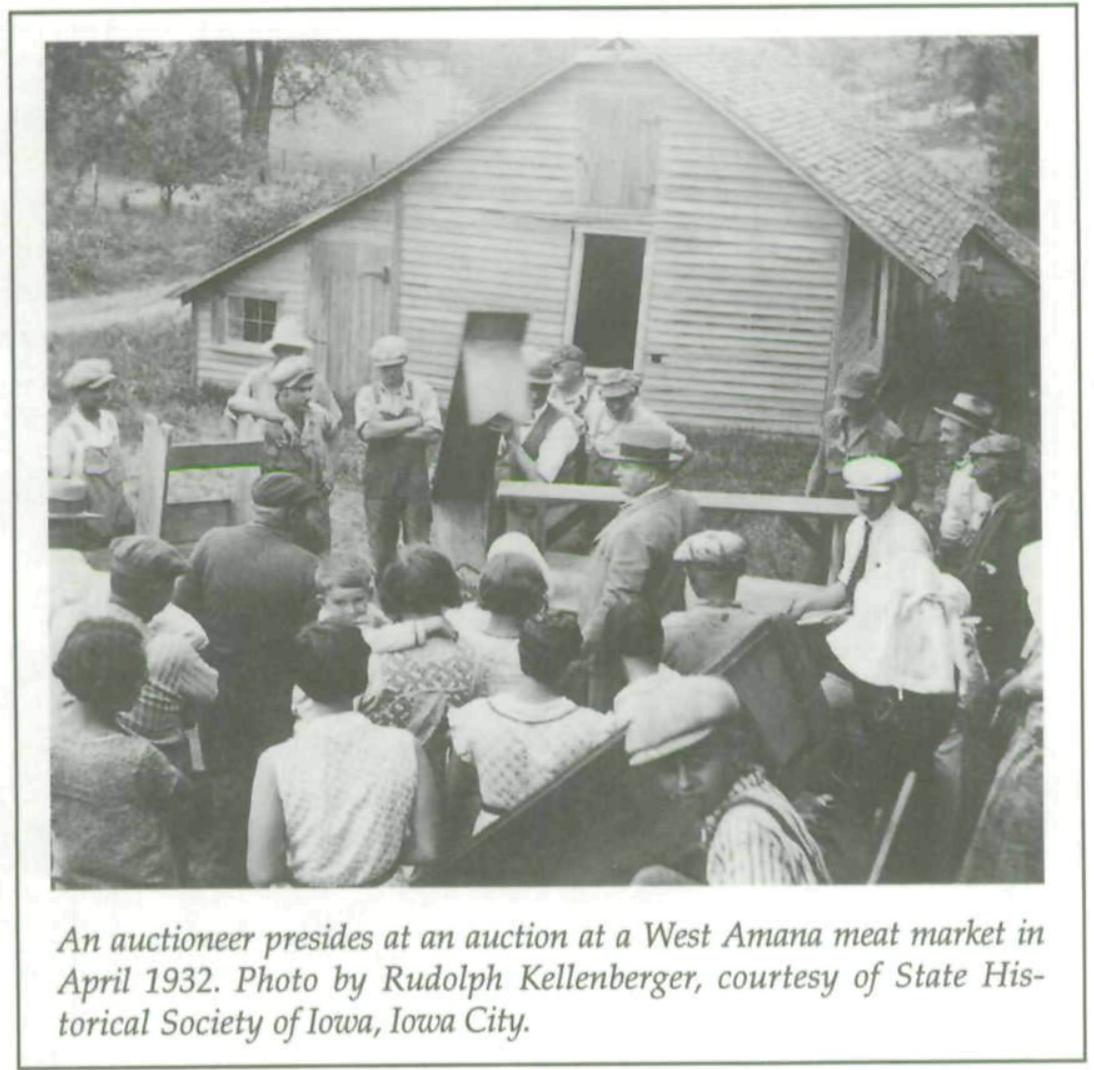

In the days surrounding the close of the kitchens, most Amana families made arrangements to cook in their own homes. In some cases a heating stove was called into service for cooking, while other families purchased small kerosene heaters from the local general stores. Many families also planted large gardens to provide them with produce for the coming year. Because residents were used to the two- or three-acre kitchen house plantings, the new gardens were huge. One resident commented, "we started a monstrous garden and hauled the cabbage and things home with a wagon, thinking we would need all this. And we never did. ${ }^{\prime \prime 47}$ Another resident, commenting fifty years later on the gardens planted that summer of 1932, said people

47. Marie Trumpold Geiger, interview by Lawrence Rettig, 21 January 1982, typed transcript, Oral History Collection, Amana Heritage Society. 
seemed to think "they would starve if they didn't raise all that [food]. ${ }^{48}$

For some women, the experience of being able to cook on their own for the first time quickly overshadowed any sadness they felt about the closing of the kitchen houses. One woman eagerly served her family canned pineapple for their first meal after the kitchens closed, the first time she or anyone else in her family had ever eaten it. For weeks following the closing of the kitchens, another woman recalls, residents who met on the street would ask each other what they had to eat the previous night. ${ }^{49}$

Because the village elders had assigned some women to work in the kitchen gardens under the communal system, they had little or no cooking experience. While speaking to a group of Marengo businessmen about the reorganization, a Homestead man was asked if all Amana women knew how to cook. According to the local paper, he replied that "his wife had been cooking two days and he already had suffered an attack of indigestion." The wife, who was present, swiftly countered that her husband's suffering was due more to overloading on her wellprepared meals than anything else. ${ }^{50}$

To accomplish the business reorganization of the old Society, outside help was needed, so the Society hired Arthur Barlow, a young businessman from Cedar Rapids, to serve as its business manager. Barlow, who had been a bank examiner in Minnesota prior to coming to Cedar Rapids, quickly instituted reforms within the Society. Among other changes, he initiated a doubleentry bookkeeping system. He also ordered the closing of shops that he believed would be unprofitable or that were simply extraneous. Some semi-profitable businesses, such as the Main Amana harness shop, stayed open with limited hours. ${ }^{51}$ Among the shops that were closed were the various broom shops, the watch repair shop, the umbrella makers, the shoe shops, and

48. Marie Franke, interview by Gaycia Neubauer, 23 March 1982, typed transcript, Oral History Collection, Amana Heritage Society.

49. Hoppe, Seasons of Plenty, 219-20; Helene Hergert Hoehnle, personal conversation with author, 1 March 1998, notes in author's collection.

50. Marengo Pioneer-Republican, 14 April 1932. The couple who made this public exchange divorced a few years later.

51. Helene Schmieder Rind interview. 


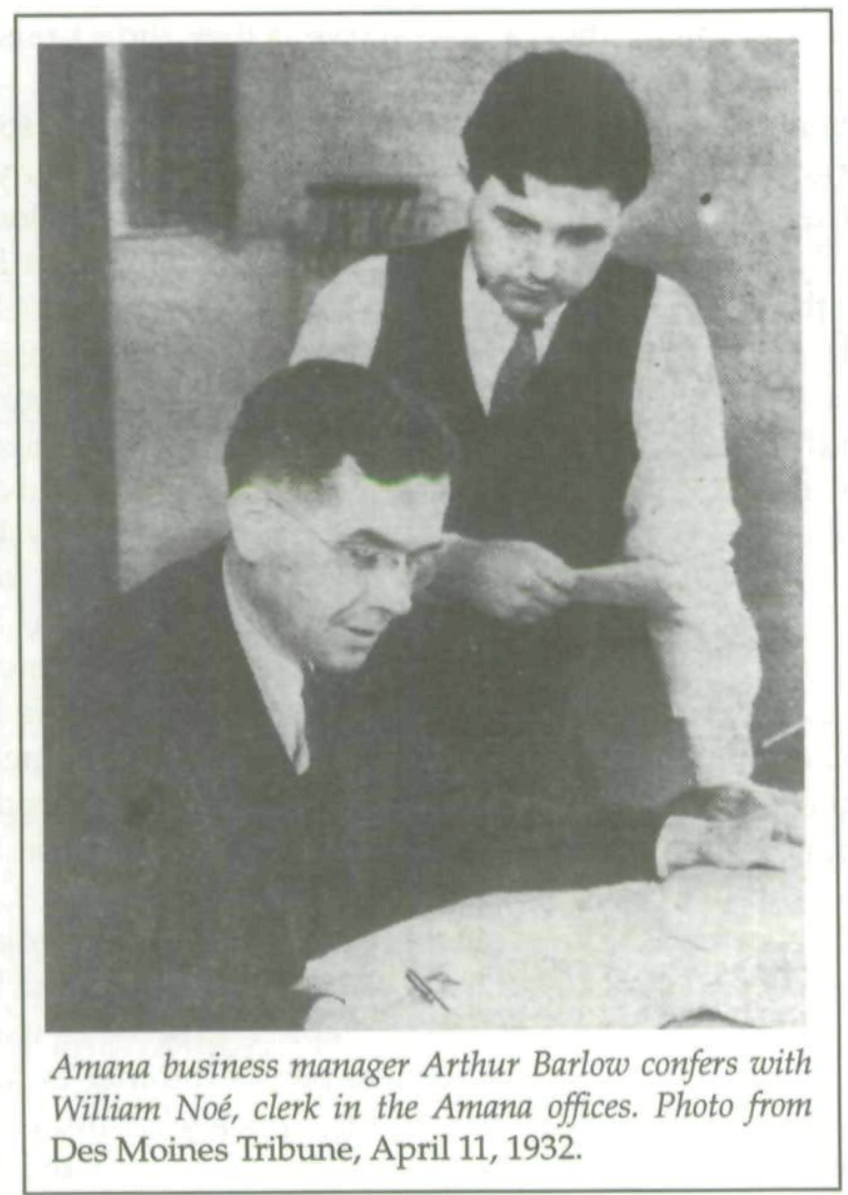

the village apiaries. Short letters informed each shop manager of their business's closure. ${ }^{52}$ Managers were offered the opportunity to work for the Society in some capacity, or they could purchase their shop's equipment and form new entrepreneurial

52. The terse letter received by Homestead broom maker Carl Hess was typical: "Dear Mr. Hess, Please be advised that the new system will go into effect next Monday morning, May 2nd. Also please take notice that your shop is to be closed, at least for the time being. Later on we will give further consideration as to the matter of shops and then either continue to operate them by the society, sell or rent to the individual, or close some of them permanently. Yours truly, Arthur Barlow, Business Manager." Arthur Barlow to Carl Hess, 27 April 1932, 1932 Reorganization Collection, Amana Heritage Society. 
businesses. Barlow bore some criticism for these actions, but his personal delivery of those letters and his willingness to do everything possible to soften the blow won him many friends in Amana.

The crucial nature of Arthur Barlow's leadership, often overlooked in favor of praising native Amana leaders, is clear. A capable businessman, Barlow was able to bring sound business and accounting procedures to an organization that needed them badly. As an outsider, Barlow was also able to make difficult decisions, such as closing unprofitable shops, that would have been even harder, if not impossible, for an Amana leader to make. Despite his ability to bring hard-nosed business practices to the Society, however, Barlow also wisely realized the importance of respecting the Society for what it was, which often meant respecting traditions and practices and making an effort to draw management and workers from Society ranks. In later years Barlow often remarked to a longtime Society official that he had purposely avoided hiring accountants and the like from Cedar Rapids. He thought it more important, if less efficient in the short term, for Amana members to learn and master those tasks for themselves. ${ }^{53}$

On May 2, 1932 (a year to the day after the first General Committee meeting), the reorganization process formally began with the opening of the Amana Society's main office in a wing of the old Main Amana General Store. Here were housed the offices of the business manager, his assistants, the Society treasurer, and the corporate secretary. The new Amana Society board of directors, at a meeting held that same day, selected the officers of the new corporation. They included Henry Moershel (president), Gustav Miller (vice-president), Peter Stuck (secretary), and William F. Moershel (treasurer). Moershel was the only officer of the old Society to remain in office in the new corporation. ${ }^{54}$

53. Reorganization leader F. William Miller, according to his daughter, always viewed Barlow as the real savior of the Amana Society. Today, devotion to Barlow remains high among his surviving Amana associates, many of whom refer to him respectfully as "Mr. Barlow."

54. Minutes, Amana Society Board of Directors, 2 May 1932, Amana Society Archives. 


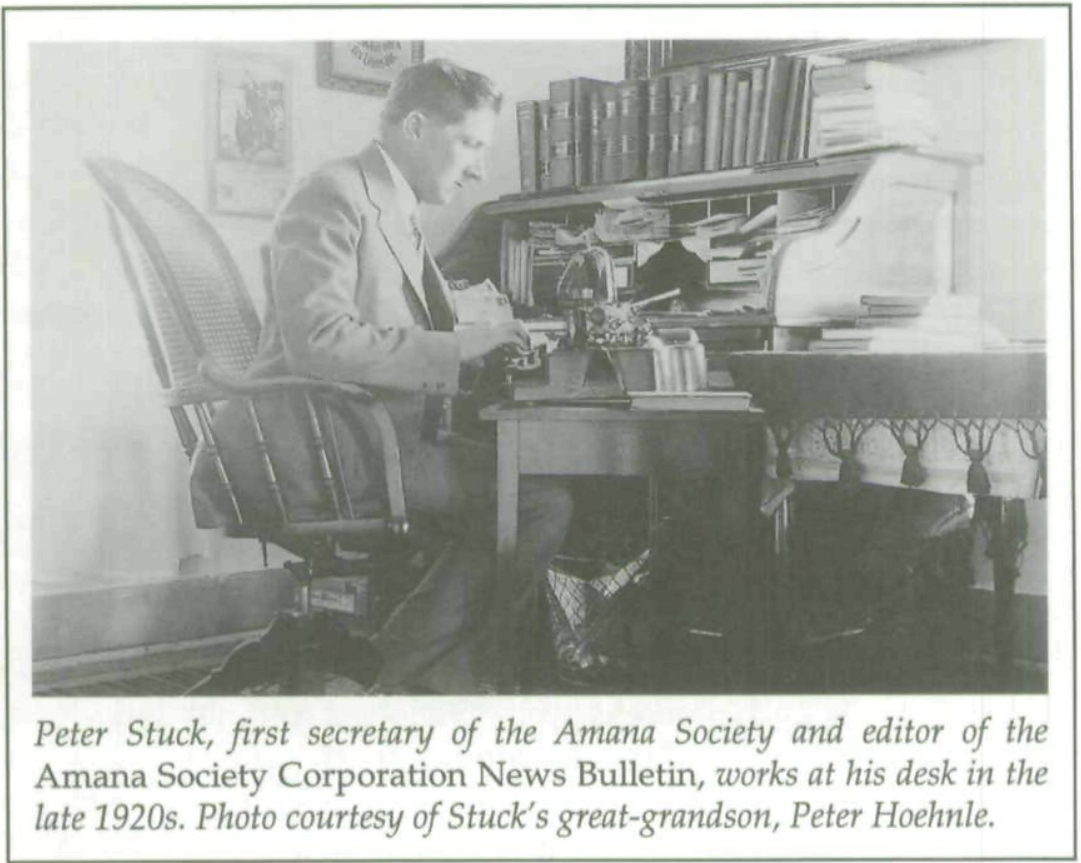

On May 12 the Society distributed the first issue of its own newspaper, the Amana Society Corporation News Bulletin. The Bulletin, as it came to be known, was an informational sheet that kept Society members informed about the reorganization process. Over the course of several months, it developed into a community news organ with regular features and even columnists.

On the day the reorganization formally began, all Society workers started receiving a uniform wage of ten cents per hour. During a period of transition that would formally end on January 1,1933 , while workers received the low uniform wage, the Society continued to permit all members to live in their homes rent free, guaranteed work for all, paid all medical bills, and made goods available from the general stores at wholesale prices. ${ }^{55}$

Although most elements of the reorganization occurred on May 2, the simple legal act to formally end the existence of one of the longest-lived communal societies in the history of the

55. Minutes of the Committee of Forty-Seven, 2 November 1931, Amana Society Archives. The Amana workers' wage of $10 \AA / \mathrm{hr}$. compares to an average wage of $50 \AA / h r$. for wage earners in manufacturing industries in 1932. 
United States did not occur for another month. On June 1, 1932, at 4:15 p.m., the county recorder of Iowa County registered a deed transferring the churches and schools of the old Society to the ownership of the Amana Church Society. At 4:30 he registered a second document deeding the rest of the old Society's property to the new corporation. ${ }^{56}$

William Moershel, the secretary of the old Society, and one of the two men who presented the deeds at the recorder's office that day, wrote a short postscript to his record of the last meeting of the Society's board of trustees. After noting that the end of the old Society was due, in part, to the members' neglect of spiritual life, Moershel wrote that he hoped the members would hold true to their fundamental beliefs so that God would "remain our leader and guide, and will not withdraw his blessing from us, but his blessed covenant of faith and mercy shall remain until eternity." He concluded, "So help us God. Amen." ${ }^{57}$

THE NEW BOARD OF DIRECTORS eagerly pursued means of increasing the Society's revenue in the midst of a nationwide depression. One proposal that won quick and early approval was to open gas stations along the highways in Homestead and Amana. One such station already existed in South Amana. Barlow and some other leaders of the Society argued briefly about the architecture of these new buildings. The "outsider" Barlow urged the use of traditional Amana materials while the residents wanted gas stations like those seen elsewhere. Barlow ultimately triumphed, and the stations, constructed from brick salvaged from the abandoned Amana Calico Factory, opened in the fall of 1932. A team of older men who were otherwise unemployable cleaned and prepared the brick for construction. Thus, like the New Deal programs then just beginning, the Amana Society found work projects to keep their people employed while performing a useful service. ${ }^{58}$

56. Iowa County Land Deed Records, Book 81/82, pp. 213-23, Iowa County Recorder's Office, Marengo.

57. Minutes, Board of Trustees, 31 May 1932, translated by Helene Rind and Peter Hoehnle, Amana Society Archives, Amana Society Main Office, Amana.

58. For the cultural and historical implications of the Amana gas stations, see Sculle, "Amana's First Decisions about Roadside Architecture," 462-74. 
The Society made other efforts to ensure that every member who wanted to work had a job. For months, the woolen mills, whose sales had remained at record low levels, continued to operate on shortened shifts so that the men and women who worked there would have some income. ${ }^{59}$

On the other hand, a tradition would later arise that many individuals who had professed illness under the old Society, realizing that they would be supported by the community whether whey worked or not, were suddenly "cured" of their ailments after the reorganization. Whether true or not, this suspicion gave rise to the nickname "Doctor Barlow" for the Society's business manager. ${ }^{60}$

For many men, the main difference between the old and new Society was that they now received a wage. They continued to work on the farms or in the factories as before, using the same equipment. The Society's willingness to guarantee all members a job while the world outside the community was experiencing massive unemployment undoubtedly kept many local residents from leaving the villages. In that sense, the depression may actually have had some benefit for the Society. ${ }^{61}$

The nature of certain Society industries at that time, such as farming, required a lot of workers. During the summer of 1932, the Main Amana farm department employed more than 40 men, while the Homestead farm, under its manager, Louis Selzer, employed 44. Those men worked an average of 124 hours per month. Working on the farm was hard, but, as one resident recalled, the pay "bought our groceries and we were able to move ahead, buy an automobile ... spend a little more money going to a picture show. ${ }^{\prime \prime 2}$ Although their duties had not changed

59. Bertha M. H. Shambaugh, "Amana-In Transition," Palimpsest 17 (1936), 151.

60. Frieda Schmieder Oehl, personal conversation, 4 July 1997, notes in author's collection; Carl Neumann, interview by Joan Sniezewski, 29 April 1982, typed transcript, Oral History Collection, Amana Heritage Society; Adolph Heinze interview by Barbara Selzer Hoehnle, 17 June 1982, ibid.

61. Helene Schmieder Rind interview. I am indebted to Mrs. Rind, a perceptive longtime Amana resident, for making this observation.

62. Louis Schmieder, interview by Kirk W. Setzer, 6 May 1982, typed transcript, Oral History Collection, Amana Heritage Society; Arthur Selzer, interview by Paul Staman, 4 April 1982, typed transcript, ibid. 
much with the reorganization, some Amana workers appreciated the new freedom the reorganization offered.

The shift from communal living to the new system had a tremendous impact on women's work patterns. With the communal kitchens closed, many women sought work in the new Society, while others became homemakers. Some women found employment in a special canning project known simply as "Department W," set up in the fall of 1932, through which participating women could market jellies and jam. Sadly, this venture apparently never got beyond initial production. Other women went to work in the Society's main office, where at least five women served as clerks or minor officials of the Society. ${ }^{63}$

The Society attempted to provide or create special occupations for otherwise unemployed women who, the Society leaders realized, would provide much needed income for their families. For a few years women planted the old kitchen gardens as before, but now the Society sold the produce commercially. In August 1932 the Homestead "corporation gardens," under the direction of garden "boss" Henrietta Geiger Selzer, employed 18 women who worked about 110 hours per month. Most of the women working in the gardens were married and had children. ${ }^{64}$

Still other women found work in the woolen mills. Twentyone-year-old Helene Schmieder of Main Amana, for example, began work, against her father's wishes, as a weaver, but was soon called into the manager's office, where she was invited to become his assistant. As Schmieder's remarkable business acumen became apparent, manager Peter Zimmermann gave her the duty of buying wool from area farmers. At least one farmer refused to "sell wool to a skirt," as he put it, but Schmieder eventually won the confidence of even the most suspicious suppliers. ${ }^{65}$ Following Zimmermann's sudden death in February 1933, Arthur Barlow assumed management of the mill. Realizing that the only person with a working knowledge of all mill departments was the young woman who had been Zimmer-

63. Amana Society Bulletin, 2 and 16 June, 14 July, and 1 September 1932.

64. The statistical information on the Homestead Corporation Garden was derived from the monthly time book maintained by Homestead Farm Manager Louis C. Selzer, loaned to the author by his son, Arthur Selzer.

65. Helene Schmieder Rind interview. 
mann's assistant, he came to rely heavily on her. In effect, Schmieder became the manager of the Amana Woolen Mill until Barlow could hire an outsider for the position. In later years Schmieder became an assistant manager of the mill and the first woman to serve on the Amana Society Board of Directors.

WHEN NOT WORKING, Amana residents continued to enjoy many of the same leisure activities they had before the reorganization, with some additions. Baseball, which the elders had finally allowed young people to play only a few years before, remained a popular pastime. Soon after the reorganization, one young man, whose ball-playing skills had drawn the attention of a professional scout, began playing minor league baseball in Cedar Rapids. In the ensuing years, Bill Zuber enjoyed a lengthy career as a professional baseball player, spending several years with the Cleveland Indians and New York Yankees before retiring in $1946 .{ }^{66}$ Another Amana man, Carl Flick, also enjoyed moderate local renown as a painter during this time. Flick, whose early works drew the attention of noted regionalist painter Grant Wood, became known throughout the Midwest for his depictions of Amana scenes. ${ }^{67}$

In the village of Homestead, a unique community organization known as the Welfare Club, which had started during the communal period, experienced a renaissance following the reorganization. Begun in 1919 as an effort to provide fellowship and promote such projects as constructing an ice pond for the village, the club was one of the few nonreligious organizations in communal Amana. Among its activities in the years preceding the reorganization were regular meetings and Christmas programs. The club subscribed to magazines such as National Geographic and provided residents of Homestead with many of the pleasures of small-town life found elsewhere in Iowa. ${ }^{68}$ Club

66. For Zuber's career, see Cliff Trumpold, Now Pitching: Bill Zuber From Amana (Middle Amana, 1992). Throughout Zuber's career sportswriters were drawn to the pitcher from the community where religious restrictions had once prohibited baseball.

67. See my article on Carl Flick forthcoming in Iowa Heritage Illustrated (2001).

68. Yambura, A Change and a Parting, 107-9. Yambura was a resident of Homestead during the years surrounding the reorganization. 
members included some of the strongest advocates of reorganization. In fact, the General Committee held most of its meetings in the Welfare Club's meeting room, which was ideally suited for nighttime meetings due to an early club project that resulted in the purchase of an electric generator.

Following the reorganization, the club suspended meetings for several months to allow members time to adjust to the new way of life. When it resumed meeting that September, club members voted to extend full membership rights to women, who had always participated in the club but had never been granted membership. ${ }^{69}$ This decision may have represented a move toward respecting the rights of women following the abandonment of the patriarchal communal system, or it may simply have been a practical measure undertaken by community members who were trying to find ways to provide a formal structure for residents to belong to now that the communal system was no more. ${ }^{70}$

For many young people, particularly young women, the reorganization brought a chance to attend high school, a privilege that only a few young men, chosen by the Society to become doctors, pharmacists, dentists, and teachers, had enjoyed during the communal period. In the fall of 1932 twenty young people from the various Amana villages, ranging from twelve to twenty years of age, enrolled at the high schools in neighboring Williamsburg and Marengo. The transition to a high school environment, particularly one imbued with all the things associated with "worldliness" under the communal system, proved difficult for the Amana students. Not only was their new environment strange, but many of them were not completely proficient in the use of English, and some of the older students had not been in school for years following their graduation from the eighth grade. On the first day of school that fall, Amana students attending Williamsburg High School met at noon and drove a few miles out of town to eat their lunch away from "outsiders" and to discuss their worries. Several of the students

69. Minutes, Homestead Welfare Club, 22 September 1932, Homestead Welfare Club Archives, Homestead Club House, Homestead.

70. The Homestead Welfare Club continues to function to this day, a unique survivor from communal days. See Arthur Selzer, Marie Selzer, Henrietta Ruff, and Peter Hoehnle, Eighty Years of Progress, 1919-1999 (Homestead, 1999). 
suggested returning for the final classes of the day and then never returning again. Despite this early pessimism, the Amana students, with the assistance of sympathetic classmates and teachers, quickly acclimated to high school. ${ }^{71}$

The reorganization brought some changes to the Amana schools, with the installation of an outsider, John Ruskin Neveln, as superintendent. Under Neveln's leadership, the Amana High School opened in Middle Amana in 1934. Most of the students who had been attending high school in other communities transferred to the new school. The grade schools, for the immediate future, continued to function as they had under the communal system, primarily because the Amana schools had always been public and under the supervision of the county superintendent.

From a religious standpoint, the community continued to function as before. Virtually everyone in the villages belonged to the newly organized Amana Church Society, and although the number of weekly services gradually declined from the eleven held under the communal system, reorganization seems to have had no immediate impact on the church itself. Although religion, in the form of Christian Metz's testimonies and biblical injunctions, had been used to sanction communalism, the Society never viewed that system as a specific article of faith. Unlike the Hutterites, for whom communal living is an indispensable component of the holy life, the Inspirationists viewed it primarily as an economic imperative. Thus, when economic situations forced Amana's Inspirationists to abandon communal living, the change did not undermine the tenets of their faith, although the shifting focus of power within the community considerably diminished the church's day-to-day control over the people. The church elders who voted overwhelmingly for reorganization apparently did not see it as a failure of religion. Scholar Frank Moore has argued that the reorganization, rather than representing weakness or decay within the church, actually was a sign of strength. In lending their support to reorganization,

71. Adolph Schmieder, interview by Louise Miller DuVal, 11 May 1982, typed transcript, Oral History Collection, Amana Heritage Society. Two of these students later received Ph.D.s, at least one received an M.A., and several others pursued undergraduate degrees at midwestern colleges and universities. 
Moore suggests, the elders were changing to meet the changing needs of their members. With the realization that communal living had served its purpose and was fostering an environment in which individual spirituality was waning, the elders wisely abandoned the outdated system. The continued survival of the Amana Church Society, almost 70 years after reorganization, confirms the wisdom of the elders' actions. ${ }^{72}$

The 13 church trustees who led the reorganized church were generally the same men who had served on the old Society's board of trustees, and they continued to oppose playing baseball on Sundays. ${ }^{73}$ For several months, young couples continued to come to the elders, as they had under the communal system, to ask for permission to marry. Signs of change appeared, however. At a wedding held in East Amana in the summer of 1933, celebrants danced for the first time. ${ }^{74}$

IN THE FALL OF 1933 the Amana Society began transferring homes to its members. Each home had been appraised in the spring, with values ranging from as low as $\$ 150$ to as much as $\$ 1,200$ for larger homes. The average cost for a home in the Amana community was $\$ 550$, considerably lower than the $\$ 1,700$ average that reportedly prevailed in Iowa at that time, in part because most of the Amana homes were already more than 70 years old and often in a poor state of repair. ${ }^{75}$ Beginning in November, residents were allowed to come to the main office and purchase their home using prior distributive shares. Generally, extended families occupied each residence and, in most cases, families appointed a particular member of the family to receive title to the house, with each adult member of the family contributing a few shares towards its purchase. In cases where unre-

72. Moore, "The Amana Society," 220-21, 225-26, 228.

73. Minutes, Board of Trustees of the Amana Church Society, 7 June 1932, Amana Church Society Archives, Middle Amana.

74. Caroline and Clifford Trumpold, "The Great Change," 5.

75. The average cost of homes in Amana and that of homes in the area were reported by Richard H. Roberts to Benjamin Franklin Shambaugh in a 1934 field report, now in the Amana Society Collection, State Historical Society of Iowa, Iowa City, Iowa. Roberts studied the Amana Society as a graduate student in political science at the University of Iowa in the 1930s. 
lated families occupied the same house, they usually established some form of joint tenancy. The Society transferred most of the homes very quickly, although the last transfer did not occur until $1938^{76}$

On January 1, 1933, the transition period formally ended, and Society workers' wages were adjusted. At the Society's first formal annual meeting in February, all of the members met to discuss the Society's fiscal operations. The treasurer reported that the Society had managed to run at a loss of only $\$ 1,025$ for the previous year." As Barlow noted in his report of the meeting, the beginning of the year had seen the Society heavily in debt and still under the communal system. A year later the officers of the new corporation could report an increase in business activity to a crowd of stockholders who were, for the most part, employed and owners of their own homes. ${ }^{78}$ Far from feeling threatened by financial disaster, the members of the Society could feel a measure of security as they left the Main Amana church building that day. Their new corporation was on a sound footing, and business prospects were improving as the darkest years of the Great Depression were soon to be left behind. Members knew that, as long as the Society lasted, it would provide a job for them. They knew that if they became ill the Society would pay their medical bills under the terms of the Articles of Incorporation. They could also point with satisfaction to the church's survival of the transition. The younger members could now imagine their children attending high school and perhaps even college. The future, although not entirely bright, was far more hopeful than it had been a year before. The Amana people had transformed themselves; they had staved off the impending bankruptcy and were well on the way to establishing a comfortable standard of living for themselves. The an-

76. An article in the Williamsburg Journal Tribune, 29 September 1938, noted the transfer of the last home. This last transfer was an exception, as very few homes were transferred after April 1933.

77. Treasurer's Report, in Minutes, Annual Stockholders Meeting, 13 February 1933 (bound with the minutes of the Amana Society Board of Directors), Amana Society Archives.

78. Minutes, Annual Stockholders Meeting, 13 February 1933, Amana Society Archives. 


\section{THE ANNALS OF IOWA}

nual meeting of 1933 proved that the reorganization had been a success - so far. Fifty years later one of the last survivors of the forty-seven-member committee elected in April 1931 to consider reorganization, when asked to assess the success of the change, remarked, "It is still too soon to tell."

79. A. T. Berger of South Amana, quoted in Emilie Zuber Hoppe, "Amana's Quiet Revolution," Wilkommen 6 (Winter 1987), 11. 
Copyright of Annals of Iowa is the property of State of Iowa, by \& through the State Historical Society of Iowa and its content may not be copied or emailed to multiple sites or posted to a listserv without the copyright holder's express written permission. However, users may print, download, or email articles for individual use. 